\title{
日本酒復活への期待と課題
}

長期にわたって消費の減少をきたしてきた日本酒に明るい兆しが見え始めている。この機会を逃さず日本 酒の復活を確固たるものにするため, これまで低迷してきた要因を分析するとともに, 酒質の見直し, 酒税 法改正に潜む製造技術的な問題点，消費動向調查の必要性などについて解説いただいた。

\section{佐々木 定}

\section{1. はじめに}

各種経済統計指標をみると景気は確実に上向き，日 銀は 2006 年 7 月にゼロ金利政策を解除して 1990 年代 から始まったデフレ時代の異常な政策から正常化へと 向かった。

酒類業界においては 2006 年 4 月に, 1962 年に大改 正された酒税法が半世紀近くを経て酒類間の税負担格 差の縮小を目的として体系の見直しが行われ簡素化さ れた。しかし今回の見直しは抜本改正までの暫定処置 であり, 今後再調整されると推考されている。

市場は業務用市場の回復で復調していたビールは梅 雨の長雨などの影響で需要が盛り上がらず, 発泡酒・ 缶チューハイの低迷, 絶好調であった焼酎ブームにも 陰りがみられるようになり, そして第 3 のビールは好 調に推移，スパークリング・ワインも急増と需要状況 は変化して, 各酒類の最近の消費動向から長期の消費 不振を続けていた日本酒にも復活の好機が到来してい ると云えるだろう。

本稿では最初に，この $2 \sim 3$ 年の本誌で論じてきた 酒類市場規模などの概況を纏めた。

そして民族酒としての日本酒の長期の低迷の根底に は, 日本文化の変化などの避けることが出来なかった 原因があると考えられ，ここに消費減少の基本的な要 因を分析した。

また前稿 ${ }^{1)}$ から重複するが, 日本酒の酒質評価の観 点を変えて, 醸造技術者としての立場と一消費者とい う視点の両面から現状の酒質を論じたい。

製造に関しての税制改正で戦後の遺産と言われてい
た三倍増醸酒が日本酒の範疇ではなくなった。しかし この製造方法の税制改正は今後の日本酒業界の酒造り の動向を見なければ改正の良否判断は出来ない多くの 課題を持っていると筆者は考えている。ここでその問 題点も提起していきたい。

総務省の消費者物価指標の内, 酒類別価格指数の変 化から見た今世紀に入ってからの日本酒の市場価格の 低下は他の酒類に比較して大きく, 経営に与えている 影響は大きい。新酒税法（以下, 新法と略記）におけ る新製品の開発には, 日本酒市場の価格競争を念頭に おいて, 日本酒の消費への悪影響がないように慎重な 検討が必要だろう。

また製造方法別課税出荷の容器別分類, 日本酒の消 費市場分類，日本酒全体の低価格酒の比率（それぞれ 推定値）についても考察して, 調査の必要性を提言し たい。

\section{2. 酒類市場規模などの変遷と現況}

酒類全体の市場規模などは次のように変化してきて おり，全体的に縮小している。

(1)全酒類の課税出荷数量は次第に増加して, 1992 年 のバブル崩壊後も消費者の嗜好が低アルコール酒へ とシフトしていくなかで, 1994 年には 1,000 万 $\mathrm{k} l$ と飛躍してその後 2000 年までの 7 年間は酒類業界 最大の消費量 1,000 万 $\mathrm{k} l$ を確保したが, 2001 年か らは本稿第 4 項のような要因によって消費量は減少 傾向にある。

(2)酒類の市場規模は 1992 年にはほぼ 7 兆円になった が, 経済不況と酒類メーカー各社の新製品開発によ 


\begin{tabular}{|c|c|c|c|c|}
\hline 年次 & $\begin{array}{l}\text { 全酒類の課 } \\
\text { 税出荷数量 }\end{array}$ & $\begin{array}{l}\text { 全酒類の } \\
\text { 市場規模 }\end{array}$ & $\begin{array}{c}1 \text { 世帯当たりの } \\
\text { 酒類支出金額 }\end{array}$ & $\begin{array}{l}1 \text { 世帯当た } \\
\text { りの飲食代 }\end{array}$ \\
\hline 1985 & 764 万 $\mathrm{k} l$ & 5 兆 4234 億円 & 48,141 円 & 15,704 円 \\
\hline 1990 & 932 & - & 53,832 & 17,003 \\
\hline 1992 & 987 & 6 兆 8643 億円 & 53,323 & 19,016 \\
\hline 1994 & 1007 & - & 55,945 & 19,780 \\
\hline 1998 & 1010 & 6 兆 6600 億円 & 52,696 & 19,389 \\
\hline 2000 & 1002 & - & 49,994 & 18,499 \\
\hline 2001 & 997 & 6 兆 0000 億円 & 48,052 & 17,931 \\
\hline 2002 & 973 & $\begin{array}{r}5 \text { 兆 } 9000 \text { 億円 } \\
\text { (推定值) }\end{array}$ & 47,502 & 17,257 \\
\hline 2003 & 959 & $\begin{array}{c}5 \text { 兆 } 9000 \text { 億円 } \\
(\mathrm{l})\end{array}$ & 46,400 & 16,851 \\
\hline 2004 & 966 & $\begin{array}{c}5 \text { 兆 } 9000 \text { 億円 } \\
(\mathrm{l})\end{array}$ & 46,011 & 17,605 \\
\hline 2005 & 945 & $\begin{array}{c}5 \text { 兆 } 8000 \text { 億円 } \\
(\mathrm{N})\end{array}$ & 45,671 & 17,515 \\
\hline
\end{tabular}

つて低価格商品の市場が拡大して現状では 6 兆円弱 と市場は縮小した。

(3) 1 世带当たりの酒類支出金額は1994 年が最大の 55,945 円で，その後は減少し 2005 年は 45,671 円 となり，市場規模の縮小に影響を与えた。

(4) 1 世帯当たりの飲食代も 1994 年が最大の 19,780 円 で，その後は減少し 2005 年は 17,515 円となってい る。

このような市場規模の変遷の中, 日本酒の消費量は 減少の一途を辿ったが，これにはわが国独特の要因が あったと考えられ, 第 3〜4 項でその減少の原因につ いて考察してみたい。

\section{3. フランス人とワインとのかかわり}

各国の民族酒は減少しているとは云ってもそれぞれ に高い市場占有率を有し, 2003 年のフランスのワイ ンは $54 \%$ のェアーを保っている。

筆者はフランスを訪問してワインに関して次のよう な経験をしたことがある。

十数年前に視察団の一員として地方都市を訪問し 「日本から投資ミッション来たる」と大歓迎を受けた。 技術学園都市グルノーブルの訪問前夜夕方遅く到着し て, 各人の夕食のオーダーも終わり通訳が案内役の政 府官僚に伝えた途端に「今日皆様のために準備してお
ります特別なワインと今皆さん方のオーダーされた食 事とは合いませんので, 今のオーダーを変えて下さ い」と云われた。一行は連日の強行軍による疲労と遅 い夕食のため空腹を抱えて再び読みなれないメニュー を眺めなくてはならなかった。これ程にフランス人の 酒質に対する思い込みは強い。

訪問した土地・土地でもその食卓にでるワインやミ ネラルウオーターはその地方の生産物であって, 食事 中はその食卓に出ている郷土の産物の話, その地方の 特色が話題となり, 郷土愛の強さを実感した。この郷 土愛こそが愛国心へと繋がり, ワインの国酒としての 地位を確固たるものとしているのであろう。

また筆者の親しい友人がパリを訪問したときに或る 酒販店でビィンテージの高級ワインを見つけた。彼は これを大枚はたいて購入し帰国の途についた。空港で の税関検査でこのワインを見た検査官は「これはフラ ンスの誇りである」と言って税関検査官から思いもか けなかった直立不動の敬礼を受けたと話していた。こ の例からしても国民のワインに対する愛着と親しみの 深さが分かる。

\section{4. 国酒・日本酒はなぜ長期の低迷をしてきたの だろうか}

戦後 $30 \%$ 以上を占めていた瑞穂の国, 日本の国酒 
である日本酒のシェアーは次第に減少して, 現状では 予想もしなかった $8 \%$ を切って苦戦を強いられている。 日本においても紀元前に稲作農耕文化が大陸から渡来 して米の酒が造られ, それ以前にも陸稲の酒があった とも云われ ${ }^{2)}$ その歴史は古く, 歴史と伝統の文化「日 本酒」に対して日本人の思いはフランス人のワインに 劣らず深い筈である。それにもかかわらず，なぜ長期 の低迷をしたのであろうか。酒類全体の消費量も減少 しているが，その原因としては前稿で指摘した通り(1) 経済不況, (2)人口構造の変化, (3)核家族の増加, (4)若 者の酒離れ，(5)団塊の世代の高齢化，(6)車社会の到来， (7)飲酒量の減少

などが考えられるが, これらは酒類全体の消費減少要 因であって, 日本酒の減少理由としてはこれらの要因 とはまた別に，

第 1 亿教育面で論議されている郷土愛・愛国心など の欠如

第 2 に日本文化が変化・衰微して日常生活が西欧化 したこと

第 3 に各家庭の生活水準が向上したことと同時に, 家族揃っての食事の減少と食の伝習が低下したこ と

が挙げられるであろう。

先日テレビで著名な女流評論家が「世界中で最も愛 国心の欠如している国は日本である」と言っていたが, 戦後教育によって郷土に対する愛情・愛国の精神が希 薄になり, 郷土や国の特産物への愛着も薄れてきたと 云っても良いだろう。また江戸・明治・大正時代, 昭 和の初期・中期に見られたように，各地にそれぞれの 特徴があった日本文化である町並み・建物・その土地 の食物・祭りなどが次第に変化・衰退・消滅して, 古 き良き時代を象徵する各地方に伝承されてきた言語・ 方言も衰微し, 日本古来の生活文化が希薄になったと 云える。そして日常の生活も畳から椅子・テーブルへ, 食事も肉・牛乳・乳製品・油脂類へと変化し, その消 費量は 1960 年代から激増し 3 5 倍となって ${ }^{3)}$, 和食 から洋食へと変化した。これらに伴って歴史と伝統の ある日本文化のひとつである日本酒も次第に日本人の 日常生活から離れ, 日本古来の主食である米の需要の 減少と共に日本酒の消費も減少してきた。特に食生活 の変化は, 淡麗な味の日本酒だけではこの食の変化に 対応することが出来なかったために，ビール・焼酎・
リキュール・ワインなどの需要が増加したと云っても 過言ではあるまい。

戦後, 酒類といえば台所にあった日本酒と焼酎の一 升瓶という生活から, 日常生活水準の向上により現在 では各家庭の冷蔵庫にはビール・発泡酒・第 3 のビー ル，居間の棚には吟醸酒・本格焼酎・ワイン，キッチ ン横には紙パックの日本酒・焼酎が並んでいる。晚酌 にはそれらの酒類が消費されることになる。また飲料 店での会合に扔いても各人がそれぞれ好みの酒を注文 して飲むのが通常のパターンになっている。

このような国内社会情勢の変化や日本文化の衰退と いう激流に押し流されて, 日本酒は長期の消費減少を 余儀なくされてきた。しかしこれらの要因による減少 傾向にも陰りがみられるようになり「日本酒」に対す る需要はここに来て復活の兆しを見せている。

すなわち消費減少から復活へと業界の懸命な様々な 対応策の効果も見え始め, 2005 年秋からの首都圈・ 中京圏の業務用市場での日本酒の需要増加や同年の課 税数量復調の兆し, 本格焼酎ブームの沈静化, 2006 年の各メーカーの出荷数量の復調傾向などの動向がみ られるようになり, 長期低迷をしてきた日本酒の消費 減少にも歯止めがかかりはじめた。これ迄とは異なる 待ちに待った日本酒復活の大きな流れが近づいている と筆者は考えている。

\section{5. 日本酒の酒質を考える}

日本酒の品質評価基準は, 級別審査では香味にクセ のない味のすっきりしたキレイな酒を良酒として判定 し，また全国新酒鑑評会・各国税局の鑑評会において は香りの高い淡麗な軽い酒質に対してそれぞれ金賞・ 優等賞と評価してきた。

長期間にわたるこの酒質評価基準によって, 製造現 場は淡麗な酒質を目標として技術改善を行い, 精米歩 合・製麹操作・酵母の選択・発酵温度・粕歩合・貯蔵 温度などの製造技術は吟醸化路線を辿り, 酒質は全国 画一化した。そして前稿 ${ }^{1)}$ で指摘した通り市販酒は特 定名称酒を含めて香りを重視した酸度・アミノ酸度の 低い淡麗薄口酒になって, 香りの高さ・味のキレイさ では大きく進歩したが，コク・旨味・円熟味に欠けた 酒質となり, 本来日本酒の酒質の表現であった「コク があってキレがある」の言葉は, 日本酒業界ではほと んど聞かれなくなり，その反面ビール業界がテレビや 
新聞広告で新製品発売の PR 用語としてこれを活用し ている。

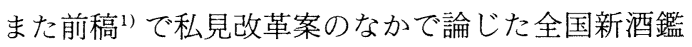
評会については, 主催者・共催者・後援者などの検討, そして鑑評会の企画・運営の検討も当然必要ではある が, 最も重要なことは日本酒全体の酒質の基本となる べき金賞該当酒の酒質基準の改革である。すなわち現 状では消費者が求める飲んで美味しい酒の審査ではな く, 審査酒としての審査となっており,「香り審査」 となっている審査基準の是正が必要であろう。長期の 低迷を続けている日本酒復活のためには, 消費者の二 ーズと離れてしまった鑑評会の審査方法を是正して, 「味吟醸」の金賞受賞が可能となる審査基準の検討が 必要であり, 審査員も生販各層からの選出が望ましい。 この軌道修正の取り組みは前稿でも指摘した通り官・ 民を問わず酒造技術者の責務でもあろう。

和食料理で味合うことが出来る, キレイな味の中に 上品な「旨味」「コク」を探求していくことは, 単に 味のキレイな料理の調理よりも高度な技術が必要であ り,「香り吟醉」から「味吟醸」すなわち「味のキレ イさに加えて旨味のある吟醸酒」への転換には, 製麹 操作その他酒造り技術全般の再検討が必要である。

日本酒復活の好機到来の時期とともに日本酒全体の 酒質を振り返り, 淡麗薄口になった酒質の見直し, 全 国新酒鑑評会の「味吟醸」の入賞の検討,「旨味」「ご くみ」「おし味」「コク」「ふくらみ」「円熟味」「濃醇 味」「熟成味」などと表現される日本酒本来の醸造酒 としての味への取り組みを望みたい。

醸造酒としての旨味を持った日本酒が酒販店に並び, 家庭の晚酌でも「明日もまた飲みたい日本酒」となり， 何処の料飲店に入っても「美味しい日本酒」「美味し い燗酒」「美味しい吟醸酒」が飲めるようになること が，日本酒復活への道であると云えるだろう。

\section{6. 新法の酒造りの課題および高価格商品の検討}

2006 年 5 月に施行された酒税法また承認基準など は, 齋藤氏 ${ }^{4)}$ が本誌に提唱した案どおりに副原料が米 の重量の $50 \%$ 以内に, また糖類を醪中での発酵が可 能となるなど改正が行われた。従来の固定化した副原 料を使用した場合と異なって, 大きな技術改革が可能 となり, 酒の濃さ・旨味・ゴク味などの点で酒質改良 が期待され, 現在の日本酒の酒質, 特に経済酒の問題
点である旨味が不足した淡麗薄口の酒から「旨味」 「ゴク味」を持った酒質へと, 酒質の多様化への前進 が計られることになったことは喜ばしいことである。

しかしここに2〜3の問題点がある。日刊経済通信 社の調査によると日本酒商品の約半数を占める紙パッ ク製品の消費数量は 2004 年に 35 万 $\mathrm{k} l$ で，その内の 凡そ $90 \%$ の 31 万 $\mathrm{k} l$ が経済酒であり, また本稿の第 8 項で述べるように瓶製品も含めると, 日本酒全体の $60 \%$ が経済酒となっているが, その販売市場は厳しい 状況にある。

このように経済酒の販売競争激化への対応策として コストダウン, 酒質の向上, 醸造工程とブレンド作業 の簡便さから推考して, 原材料の表示の問題はあるが, 新法の造りでは糖類添加製品の比率が高くなる可能性 があると考えられる。また今後の集計では米を加水分 解して精製した糖類がプラスされることになる。

新法の酒造りでは糖類添加酒に使用される原料白米 の数量はこれまでの $8 \%$ から $20 \%$ 程度（推定值）まで 増加すると予測される。また紙パック商品の内一般酒 は $85 \%$ である（本稿第 2 表参照）が，この一般酒 30 万 $\mathrm{k} l$ がすべて新法方式で醸造された場合には, 粗計 算では糖類の使用量は現行使用量の約 2 倍になると試 算される。また糖類を原材料の 1 つと割り切って, 上 撰・佳撰クラスの一般酒も糖類の醪中での発酵などに よって品質の向上と精米歩合の再検討などを含むコス トダウンを計った商品の企画が増えることが考えられ, 本年の製造結果が注目される。

各企業の経営方針によるが, 今後はメーカー各社が 新法による酒造りによって，それぞれの市場に見合っ た商品としての日本酒ベースのリキュールなど新しい 商品企画の取り組みが高まる可能性もあると云えるだ ろう。

しかし以上の状況は業界が期待する日本酒醸造に使 用する原料米使用数量の増加に逆向し，またアルコー ル使用限度量も従来と変わらない状況下で, 消費者に 新法によった一歩前進の新しい日本酒造りとして理解 されるであろうかという懸念が残る。

新法はこのように「両刃の剣」と考えられ, 今後の 業界の酒造りの動きと新製品開発の動向を見なければ, 改正の良否の判断は出来ない幾多の課題を持っている と筆者は考えている。多くの課題を抱えた新法の酒造 りによって, 日本酒業界そしてメーカー各社は今迄に 
ない慎重な検討・判断を問われる局面を迎えているこ とは確かだ。

また新法の酒造りによって糖類添加製品の比率が高 くなることも予測される中, 瑞穂の国の国酒として, 需要が増加してきている純米酒の拡販により効果的な 戦略を練り, 純米酒の消費量の一層の増加を計ること も必要であろう。

人口減少高齢化社会を迎え, 各企業では大量生産・ 薄利多売の戦略は通用しなくなり, 付加価值の高い商 品の開発・製造に向かって生産規模は縮小していくと の松谷氏 ${ }^{7)}$ の理論から, 日本酒業界においても新法に よる酒造りの取り組みと共に, 特定名称酒の上り高価 格な商品の開発研究を各メーカーが進めていくことも 必要だろう。

前述のフランスの税関検査官が敬礼したように，国 酒として将来は日本の税関が敬礼するような日本酒を 目ざして日本酒支持層の拡大努力, 新商品の開発など の研鑚を期待している。

\section{7. 酒類別価格指数が語ること}

総務省の調查による消費者物価指数の中から全国の
酒類別価格指数の推移を第 1 表に示した。

(1)第 1 表から 2000 年の酒類全体の市場価格を $100 \%$ として 2005 年には $96.6 \%$ と低下している。

(2)今世紀に入ってからも経済不況の影響と販売競争の 激化から酒類業界の価格競争は激しく, 2005 年は ぶどう酒（輸入品）を除いてすべての酒類の市場価 格が低下していることが分かる。

(3)本格焼酎 (麦製) もここ数年の順調な需要の伸びに も拘らず，市場価格は下がっていることは注目され る。

(4)ビールの価格も低下して販売競争の激化がうかがえ る。発泡酒の指数は増税の影響が出ているためと推 測される。

(5)国産ウイスキー・国産ワイン・輸入ウィスキーの価 格も低下している。

(6)清酒 A は各酒類の指数との比較をしてみると価格 の低下は小さいが, 清酒 $\mathrm{B} ・$ 清酒 C の価格指数の 変化については注視しなくてはならない。

(7)これらのデータから, 酒類業界全体の熾烈な販売競 争は如何に価格への影響が大きいかが分かるが，酒 類消費量が停滞しコストダウンにも限界のある現状

第 1 表 酒類別価格指数（全国）

\begin{tabular}{c||c|r|r|r|r|r|r|r|r|r|r}
\hline 年次 & 酒類 & 清酒 A & 清酒 B & 清酒 C & 焼酎 & ビール & 発泡酒 & ウイスキー & $\begin{array}{c}\text { ウイスキー } \\
\text { (輸入品) }\end{array}$ & ぶどう酒 & $\begin{array}{l}\text { ぶどう酒 } \\
\text { (輸入品) }\end{array}$ \\
\hline 1990 年 & \multicolumn{1}{|c|}{95.6} & 91.2 & 93.2 & 87.9 & 77.2 & 96.2 & - & 124.7 & 121.3 & 121.4 & 108.2 \\
92 & 97.9 & 94.7 & 95.8 & 93.9 & 82.2 & 97.2 & - & 124.7 & 129.8 & 121.6 & 121.6 \\
94 & 99.7 & 96.7 & 97.7 & 97.4 & 85.6 & 99.2 & - & 124.7 & 120.0 & 121.6 & 110.4 \\
96 & 100.1 & 98.5 & 99.1 & 98.9 & 87.3 & 99.8 & - & 124.2 & 112.6 & 106.3 & 101.2 \\
98 & 100.6 & 100.2 & 100.5 & 100.3 & 97.6 & 101.0 & - & 102.5 & 102.9 & 101.5 & 102.5 \\
\hline 2000 年 & 100.0 & 100.0 & 100.0 & 100.0 & 100.0 & 100.0 & 100.0 & 100.0 & 100.0 & 100.0 & 100.0 \\
01 & 99.3 & 99.5 & 99.3 & 99.2 & 100.5 & 99.2 & 99.5 & 99.3 & 99.1 & 98.8 & 97.6 \\
02 & 98.4 & 99.1 & 98.8 & 99.0 & 100.2 & 98.3 & 95.9 & 99.0 & 97.7 & 97.6 & 98.3 \\
03 & 97.6 & 98.6 & 97.8 & 97.7 & 99.9 & 97.3 & 96.7 & 98.2 & 96.1 & 95.7 & 98.3 \\
04 & 96.7 & 97.5 & 96.5 & 95.6 & 99.3 & 96.3 & 97.2 & 97.4 & 94.3 & 96.2 & 97.3 \\
05 & 96.6 & 97.0 & 95.9 & 94.8 & 98.9 & 96.4 & 97.0 & 97.0 & 93.7 & 95.4 & 100.3 \\
\hline
\end{tabular}

注）清酒 $\mathrm{A}$ は特撰または特撰に相当する清酒, 本醸造酒, アルコール分 15 度以上 17 度未満, $1,800 \mathrm{~m} l$ 入り 清酒 $\mathrm{B}$ は上撰または上撰に相当する清酒, 普通品, アルコール分 14 度以上 16 度末満, $1,800 \mathrm{~m} l$ 入り 清酒 C は佳撰または佳撰に相当する清酒, 普通品, アルコール分 13 度以上 16 度未満, $1,800 \mathrm{~m} l$ 入り 焼酎は乙類, 原料麦, アルコール分 25 度, $1,800 \mathrm{~m} l$ 入り ビールは淡色, $360 \mathrm{ml}$ 缶, 6 缶入り ウイスキーはアルコール分 43 度以上, $750 \mathrm{~m} l$ 入り,「サントリーリザーブ 10 年」 ウイスキー (輸入品), スコッチウィスキー, アルコール分 40 度, $700 \mathrm{ml}$ 入り,「シーバースリーガル 12 年」 ぶどう酒はアルコール分 15 度末満, $720 \mathrm{~m} l$ 入り,「ビストロ」「うれしいワイン」 ぶどう酒 (輸入品)，フランスワイン， $750 \mathrm{~m} l$ 入り，A.C. ワイン「ボジョレー (赤)」

資料：総務省「消費者物価指数年報」, 平成 17 年度 
では, 販売価格の低下は即売上高に影響して, 粗利 益率の低下へと波及し経営に大きな影響を与えてい ることは歴然としている。

(8)今後の新法下の新製品開発・新商品販売については 主流清酒の販売に影響の出ないように十分な配慮を しなくてはならないと考える。

\section{8. 日本酒の消費市場分類調査への提言}

日本酒の消費市場の分類については, 過去の資料は 少なく不明な点が多いため現状の概況も定かではない。 ここに不備な資料ではあるが消費市場を分類するため の一つの考え方として 2005 年の消費市場概況（推定 值）を基に私案を示した。

（1）製造方法別課税出荷数量比率そして瓶製品(陶 器・樽なども含む）と紙パック製品の比率（推定 値)

(1) 2005 年の製造方法別課税出荷数量の比率は, 第 2 表のように特定名称酒 $25 \%$ ・一般酒 $75 \%$ とな っている。

(2)日本酒の課税出荷数量の内, $55 \%$ が瓶製品であり,
$45 \%$ が紙パック製品である。

(3)特定名称酒 $25 \%$ の内, $18 \%$ が瓶製品・7\%が紙パ ック製品となっている。

(4)一般酒 $75 \%$ の内， $37 \%$ が瓶製品・38\%が紙パッ ク製品と約半数づつである。

(5)紙パックの内 $90 \%$ が経済酒（2.0 l, 1,500 円以 下）と推考すると, 日本酒全体の $40 \%$ が紙パッ クの経済酒となる。瓶製品の内 $35 \%$ が経済酒 （1.8l，1,500 円以下）として日本酒全体の $20 \%$ が瓶製品の経済酒である。経済酒の合計は $60 \%$ となって低価格酒比率はかなり高くなっている。

(2) 消費市場の概況（推定値）

(1)級別酒の時代には, 第 3 表のように業務用市場で 45\%の需要，家庭用市場で 55\%（二級酒 45\%・ 贈答用 $5 \%$ ・一級酒の家庭用 $5 \%$ ）が消費されて いたと推測される。(贈答用は特級酒 $2 \% \cdot 1$ 級酒 $3 \%$ と仮定)

(2)現状でも業務用 $45 \%$, 家庭用 $55 \%$ (前稿5)で支 出金額ベースで家庭用 51\%であった）と推考さ れ，第 2 表の分類を考慮してそれぞれの消費状況

第 2 表 2005 年の製造方法別課税出荷数量比率

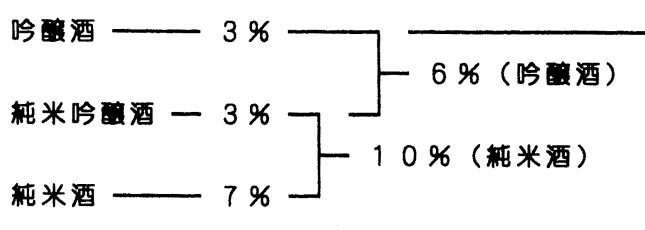

本酸造酒一 $12 \%$

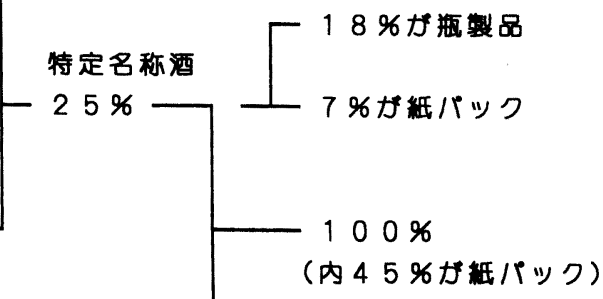

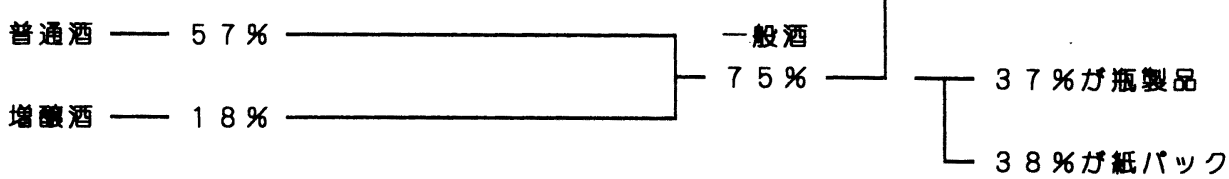

紙パッフ商品の内訳

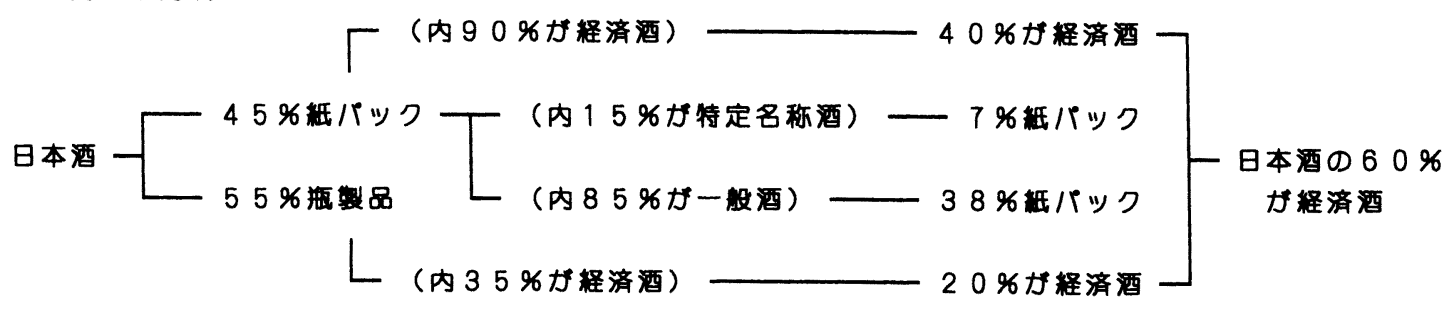


第 3 表 各名称酒と消費市場の概況（推定值）

极別酒の時代

現 在

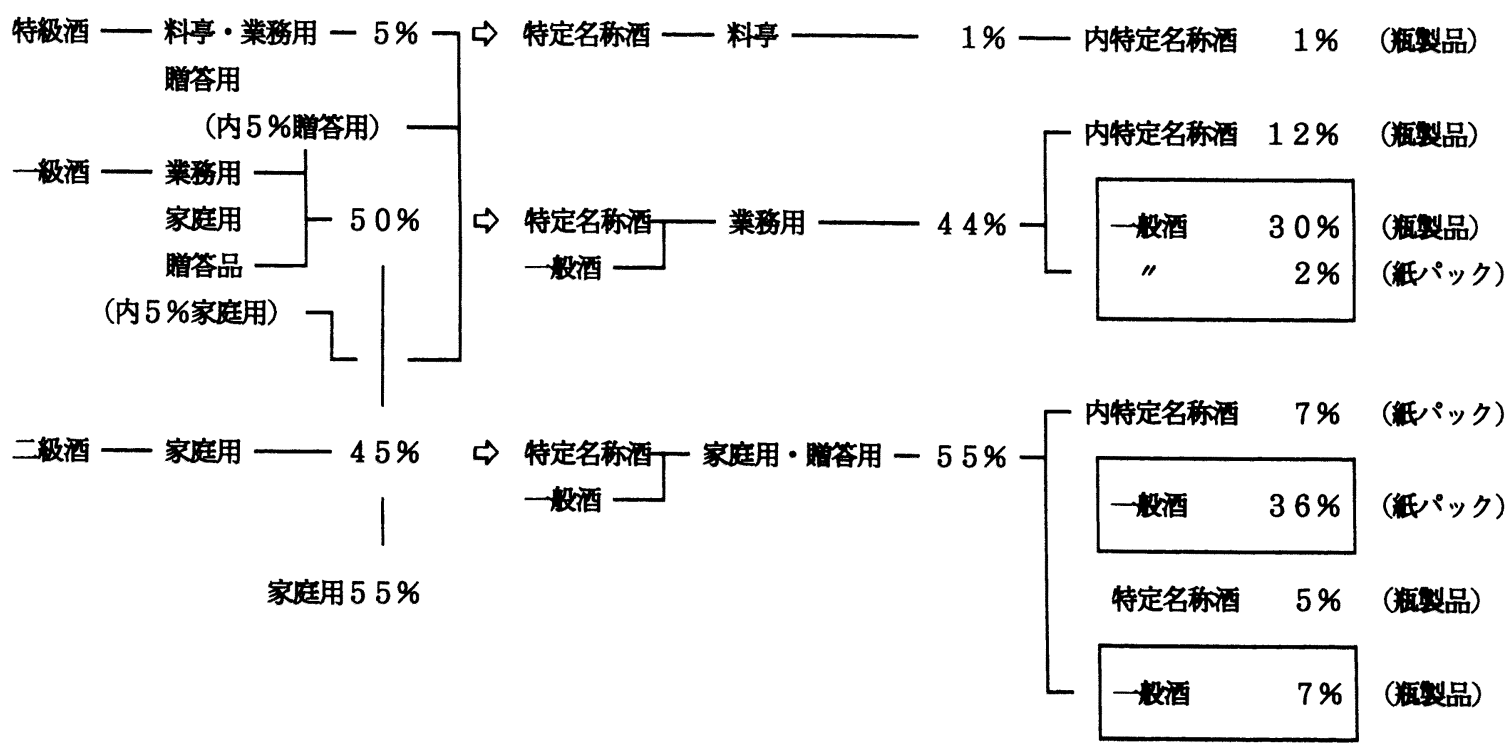

は第 3 表の右欄のようになると推測される。(贈 答用は特定名称酒)

(3)級別酒時代に地方の 2 級酒市場を占めていた地方 メーカーの市場に，現在は第 3 表の家庭用市場で 見られるように大手主力の紙パック製品が $80 \%$ 近くを占めていることが分かる。

(4)一般酒は業務用市場の $70 \%$ 以上，家庭用市場の 80\%近くを占めていて，これらの製品の品質は極 めて重要である。

(5)現状の 65 歳以上の人口は 5 人に 1 人が， 30 年後 には 3 人に 1 人になるに従って飲酒の場は必然的 に家庭での比率が高くなると推考される。従って 第 3 表右欄下段の家庭での消費は，今後の新製品 も含めて日本酒全体の中での比率が上がってくる であろうと予測される。

これらの表は日本酒消費市場の概況（推定値）を示 す私案であるが，日本酒市場の消費状況の把握と将来 を予測するための必要なデーターであり，今後私案の ような内容の調査が行われることを期待したい。

\section{9. おわりに}

今後の日本酒は消費者のニーズを見極めて，現状の
酒質を検討し，また多くの課題を抱える新法に基づく 酒造りの方向性の慎重な検討をしつつ，それぞれのメ 一カーの市場に合った新製品開発がより一層進められ ることになるであろう。

酒類別価格指数から見た酒類の販売競争は厳しく, 前稿 ${ }^{6}$ でも述べたように『酒類業界全体が流通業界を 含めて収益を重視した新しい発想による新しい流れを 作るような取り組みを考える時期に来ている』と考え る。

日本酒復活の流れがきているこの好機にこそ前稿1 で述べたような各種対策を実施し，また新法下におい て慎重に様々な新しい取り組みを進めて日本酒業界の 復権を果たすことを筆者は期待している。

なおこの内容の一部について 2006 年 7 月に京都酒 造工業研究会において講演を行った。

（追記）

飲酒交通事故の頻発により，全国的にアルコール関 連業界では飲酒運転根絶を目ざした運動を拡大させて いる。東京・大阪などの交通機関が発達した大都市は 別として, 移動手段を車に頼っている地方の都市・郡 部では飲酒店への来客数のマイナス影響が出始めてい る。その結果全国的にみるとすべての酒類が家庭での

醸 協 $(2007)$ 
飲酒比率が増加していくと予測される。関連業界の飲 酒運転根絶運動の拡大は必須の状況下にあり, 飲食店 での消費量の低下によって今後アルコール飲料全体の 消費数量に多少の影響があるとしても，筆者はこの運 動の成果が実り飲酒運転の根絶そして撲滅を切に願つ ている。(2006 年 11 月 11 日記)

〈三笠フーズ (株) $>$

\section{文}

献

1）佐々木定：本誌，101，198（2006）
2）加藤百一：日本の酒 5000 年，技報堂出版 (1987)

3）佐々木定：本誌，96，777（2001）

4）齋藤富男：本誌，96，606（2001）

5）佐々木定：本誌，99，298（2004）

6）佐々木定：本誌，100，84（2005）

7）松谷明彦：人口減少経済の新しい公式，日本経 済新聞社（2004）

執筆者紹介（順不同・敬称略）

佐々木定 $<$ Sadamu SASAKI >

本誌第 99 巻第 5 号 323 頁参照

\section{酒井 佑 $<$ Tasuku SAKAI $>$}

昭和 18 年 9 月 8 日生まれ<勤務先とその所在地> 酒井酒造株式会社, ₹ 740-0027 山口県岩国市中津町 1 丁目 1-31<略歴>昭和 41 年青山学院大学経済学部商 学科卒。昭和 60 年酒井酒造株式会社代表取締役。<趣 味>里山の散策
倉光潤一 $<$ Junichi KURAMITSU $>$

<勤務先とその所在地 $>$ (独) 酒類総合研究所, $\bar{\top}$ 114-0023 東京都北区滝野川 2-6-30<略歴>平成 7 年 九州大学大学院農学研究科農芸化学専攻修了, 同年国 税庁採用, 平成 8 年熊本国税局, 平成 13 年沖縄国税事 務所, 平成 17 年米国コーネル大学派遣, 平成 18 年同 大学修了, 同年現所属<抱負 $>$ 官能評価をとおして酒 類の特性を明らかにし, 酒類の持っている可能性を広 げたい。く趣味＞沖縄で始めたダイビング，旅行 